\title{
A Study of Mobile Banking with reference to Customer Satisfaction in Bank Nizwa, Oman
}

\author{
Al Shifa Al-harthi \\ Dr. Madhave Hejmadi
}

\author{
College of Banking and Financial Studies \\ College of Banking and Financial Studies
}

\begin{abstract}
The banking business in Oman has flourished greatly due to the adoption of technology and provision of enhanced customer service. Mobile Banking can make banking transactions convenient because customers can access financial resources even from distant areas. Technology can have a significant impact on customer service and satisfaction. The mobile banking revenues reached $\$ 8.3$ billion in 2015 and have penetrated deeper into the market and the mind of the customer. Mobile banking has made a difference in customer satisfaction. The main objective of the research paper is to evaluate the usage of mobile banking at Bank Nizwa. The research was conducted to evaluate the impact of mobile banking on customer satisfaction at Bank Nizwa in Oman. The researcher used a quantitative research design as it is aimed to measure the impact of mobile banking on customer satisfaction and get quantitative data from respondents with accuracy. Two sources of data have been used: Primary data was collected through a questionnaire with 24 items and secondary sources such as the website of the bank, articles, annual reports, bank statements and circulars were also consulted. The data was collected through an electronic survey and the list of respondents was obtained from the Bank Nizwa database. A total of 122 respondents belonging to different age groups responded The response rate was $80 \%$. Data was analysed by using statistical packages for Social Sciences (SPSS) software. Both single variable, double variable and cross tables were prepared. The statistical tests like chi-square and correlations were applied. The results reveal that there are factors influencing customers' satisfaction of mobile banking and the problems that hindered customers satisfaction were also identified. The attempt of this study was to examine the impact of mobile banking factors and services at Nizwa Bank in Oman
\end{abstract}

\section{Introduction}

Mobile Banking is an important service in the banking sector. It is very easy to use and required for the customers in terms of saving time. Mobile Banking becomes an advantageous operation to customers (Nupur, 2010). Mobile banking is also known as a form of banking transactions through mobile phone and electronic means.

Mobile banking is the fastest growing market around the world, especially in the Gulf countries and data indicates that mobile banking customers are enjoying more services on a daily basis through their devices.

\section{Mobile Banking in GGC countries}

The mobile banking sector reached revenues of $\$ 8.3$ billion in 2015 and penetrated deep in the market. The demographics of GCC countries and user profiles indicate that mobile banking has a promising future. GCC customer has $87 \%$ of users in Mobile Banking and they strongly agree that Mobile Banking offers many advantages. About 77\% of Mobile Banking customers in GCC strongly agreed that Mobile Banking Ape made payments easier. [1]

The study will discuss the problems of mobile banking and how it is affected in terms of customer's 
services as well as will find the problems that may occur while using mobile banking and find solutions to solve the problems. This study has been conducted with reference to Bank Nizwa, Muscat.

Bank Nizwa has developed customer service features to meet the needs of their customers by adopting modern technology and also to compete with other banks. [2] [3]

\section{Objective of the Research}

The aim of this study is to evaluate the impact of Mobile Banking and customer satisfaction in Bank Nizwa.

\section{The main objectives are:}

1. To evaluate the usage of mobile banking in bank Nizwa.

2. To identify the factors that influence customer.

3. To explore appropriate recommendations to improve the mobile banking.

\section{Research hypotheses}

- There are gender wise differences in customer satisfaction in mobile banking.

\section{Literature Review}

Mobile Banking operates through smartphone and it works only when there is an Internet and through this program one can operate banking accounts.

1. The study of Heba, K, Shafig, I. (2014) measured the impact of using mobile banking services and customer satisfaction on the services offered by the bank. [4]

2. The study of Kumari, K, Janaka, W (2014). The aim of this study is to know the impact of banking services on customer satisfaction at Commerical Bank in Sri Lanka as well as to determine the characteristics of the services over the mobile banking and how banks can achieve a suitable relationship with customers. [5]

3. The study of Ananda,S, Sonal,D. (2017) investigated the level of customer satisfaction on the quality of banking services in the Sultanate of Oman, the five - dimensional Seruqal model was used to examine the expected services of customers. The results of this study helped Omani banks in their strategic planning in providing services that meet the needs of customers. [6]

4. The study of (Romario, 2018) found that customers are satisfied with Mobile Banking services. The Mobile Banking converter provides consumers with easy access to their financial resources. [7]

5. The purpose of the study by Sonal \& Amanda, S. (2018)was to explore factors that can affect the quality of banks that can lead to customer satisfaction. Banks focus on customeroriented services through sustainability and growth in a competitive environment. [8]

6. The study of Ruth, J, Dennis, J, (2018), made to know the effects of Mobile Banking strategy on customer satisfaction and to identify the most important factors affecting mobile banking services for customer satisfaction. [9]

7. The study of Aiswary, S, Juby, R, Abymon, A. (2018). The aim of this study perception towards of customer with mobile banking services that provides in Bank of India [10]

\section{Research design}

This research used a Quantitative design as it aims to measure the impact of mobile banking on 
customer satisfaction.

\section{Data collection methods}

The primary source of data was a questionnaire with 24 questions of different types. It was designed to measure the impact of Mobile Banking on customer satisfaction in Bank Nizwa. 122 people completed from $150 \%$ samples with a response rate of $81.3 \%$.

Secondary sources of data were collected from bank web sites, annual report and statements, circulars and newspapers.

\section{Sampling size}

The sample size taken was 122 samples and randomly selected with 51 male and 71 female respondents.

\section{Data analysis approach}

Data was analysed by using software on Statistical Packages for Social Sciences (SPSS). Both single variable frequency tables, cross table, charts and arithmetic averages has been used, Chisquare, Correlations were applied to find out relationship between two variables, single variable, cross variable tables have been prepared.

\section{Analysis of Primary Data}

\begin{tabular}{|l|l|l|l|l|}
\hline \multirow{2}{*}{ Gender } & \multicolumn{2}{|c|}{ Number of years of bank dealing in Bank Nizwa } & \multirow{2}{*}{ Total } \\
\cline { 2 - 4 } & $\mathbf{1 - 4}$ years & $\mathbf{5 - 9}$ years & More than 10 years & \\
\hline Male & 39 & 10 & 2 & 51 \\
\hline Female & 60 & 9 & 2 & 71 \\
\hline Total & 99 & 19 & 4 & 122 \\
\hline
\end{tabular}

Table 1. Gender of the Respondents and Number of years of bank dealing in Bank Nizwa Primary Data

\section{Average bank dealings is 3.28 years}

The table shows the number of years that respondents dealing in Bank Nizwa. Females were more than Males with bank accounts Bank Nizwa.. 84.50\% of females started in the first four years. The table shows that a few customers have had their accounts at Bank Nizwa for more than 10 years. On an average customers are dealing with the bank is 3.28 years, it indicates that most of the customers are new to the bank.

\begin{tabular}{|l|l|l|l|l|l|}
\hline Gender & \multicolumn{3}{|c|}{ Nature of Bank Account } & TTotal \\
\hline Male Female Total & Saving Account & $\begin{array}{c}\text { Current } \\
\text { Account }\end{array}$ & Any other & Loan Account & \\
\cline { 2 - 6 } & 39 & 10 & 0 & 2 & 51 \\
\cline { 2 - 6 } & 47 & 16 & 1 & 7 & 71 \\
\cline { 2 - 6 } & 86 & 26 & 9 & 122 \\
\hline
\end{tabular}

Table 2. Gender of the Respondents and Nature of Bank Account Primary Data

The table shows that there no correlation between female as requires to Nature of bank Account. But a majority of the male and female having same bank Account in Bank Nizwa which they use Saving Account. Bank can publish advertisements to customers to open other accounts. 


\begin{tabular}{|c|c|c|c|c|c|}
\hline \multirow[t]{2}{*}{ Gender } & \multicolumn{4}{|c|}{ Frequency of using mobile banking } & \multirow[t]{2}{*}{ Total } \\
\hline & 11-3 times & 4-8 times & 8-12times & Over 12 & \\
\hline Male & 35 & 9 & 3 & 4 & 51 \\
\hline Female & 46 & 14 & 10 & 1 & 71 \\
\hline Total & 81 & 23 & 13 & 5 & 122 \\
\hline
\end{tabular}

Table 3. Gender of the Respondents and Frequency of using mobile banking Primary Data

The table shows the respondents of Gender and how frequently they use mobile banking services. It shows that $64.78 \%$ of female used these services 1 to 3 times and $68.62 \%$ males used mobile banking services frequently. The bank can develop mobile banking services that can help the customers to use mobile banking services; this will save customers' time.

\begin{tabular}{|l|l|l|l|l|l|}
\hline \multirow{2}{*}{ Gender } & \multicolumn{3}{|c|}{ Satisfaction of overall mobile banking services } & \multirow{2}{*}{ Total } \\
\cline { 2 - 6 } & Very satisfied & $\begin{array}{l}\text { Somewhat } \\
\text { satisfied }\end{array}$ & Neutral & Dissatisfied & \\
\hline Male & 21 & 20 & 8 & 2 & 551 \\
\hline Female & 27 & 32 & 9 & 3 & 71 \\
\hline Total & 48 & 52 & 17 & 5 & 122 \\
\hline
\end{tabular}

Table 4. Gender of the Respondents and Satisfaction of overall mobile banking services Primary Data

The Table shows the Respondents of Gender who are satisfied with Mobile Banking services in Bank Nizwa. Most respondents (82\%) are satisfied with Mobile Banking, this shows that the Respondents are convinced with mobile banking services in bank Nizwa.

\begin{tabular}{|c|c|c|c|c|c|}
\hline \multirow[t]{2}{*}{ Gender } & \multicolumn{4}{|c|}{$\begin{array}{c}\text { Assessment regarding successful of mobile banking technology in Bank } \\
\text { Nizwa }\end{array}$} & \multirow[t]{2}{*}{ Total } \\
\hline & Very high & High & Average & Low & \\
\hline Male & 27 & 14 & 9 & 1 & 51 \\
\hline Female & 14 & 38 & 18 & 1 & 71 \\
\hline Total & 41 & 52 & 27 & 2 & 122 \\
\hline
\end{tabular}

Table 5. Gender of the respondents and assessment regarding successful of mobile banking technology in Bank Nizwa Primary Data

Above table shows the Gender of the Respondents and Assessment the Bank Nizwa Successful of technology. The majority of male responded that the success of mobile banking (80\%) is very high and high. Male are more than female in Assessment of the Mobile Banking with Successful technology at Bank Nizwa. In addition, Bank Nizwa should see the problems that cannot be successful technology of Mobile Banking.

\begin{tabular}{|l|l|l|}
\hline Suggestion given & Frequency & Per cent \\
\hline $\begin{array}{l}\text { No suggestions, but excellent } \\
\text { service. }\end{array}$ & 35 & 28.7 \\
\hline $\begin{array}{l}\text { Open more branches in different } \\
\text { locations }\end{array}$ & 35 & 28.7 \\
\hline Helps to familiarize the system & 30 & 24.6 \\
\hline Improve the site speed & 22 & 18.0 \\
\hline Total & 122 & 100.0 \\
\hline
\end{tabular}

Table 6. Suggestions to improve the services of mobile banking in Bank Nizwa Primary data

The suggestion given by the customers are almost equally distributed. About $29 \%$ of the customers 
appreciated the mobile banking services in Bank Nizwa and they have no suggestions to offer. Moreover, 29\% of customers communicated that Bank Nizwa need to open more branches in different locations of Oman and $25 \%$ of customers expect the bank to give technical training them to familiarize the mobile banking systems. But $18 \%$ of the customers commented that the web site speed is not sufficient to operate the mobile banking systems.

\begin{tabular}{|l|l|l|}
\hline Satisfying factors & Yes & No \\
\hline $\begin{array}{l}\text { Bank Nizwa offers fast services such as, } \\
\text { informing the customer about } \\
\text { transaction by SMS. }\end{array}$ & $100(80 \%)$ & $22(18 \%)$ \\
\hline $\begin{array}{l}\text { Providing secure transaction through } \\
\text { mobile banking }\end{array}$ & $105(88 \%)$ & $17(14 \%)$ \\
\hline $\begin{array}{l}\text { Overall satisfaction levels of Mobile } \\
\text { Banking services of Bank Nizwa }\end{array}$ & $1(87 \%)$ & $16(13 \%)$ \\
\hline Averages of Satisfying factors & $85 \%$ & $15 \%$ \\
\hline & & \\
\hline
\end{tabular}

Table 7. Mobile Banking Services and Satisfaction factors of the customers Primary Data

It has been realized that the above tabulated data in the table reveals that the Mobile Banking of bank Nizwa has excellent satisfying factors and on an average $85 \%$ of the respondents have appreciated the fast service message of SMS when customer make transaction under mobile banking services. Customers also felt that mobile banking is providing secure transaction and overall customer satisfaction levels of the technology are at highest level. 


\section{Journal of Student Research}

Fourth Middle East College Student Research Conference, Muscat, Sultanate of Oman

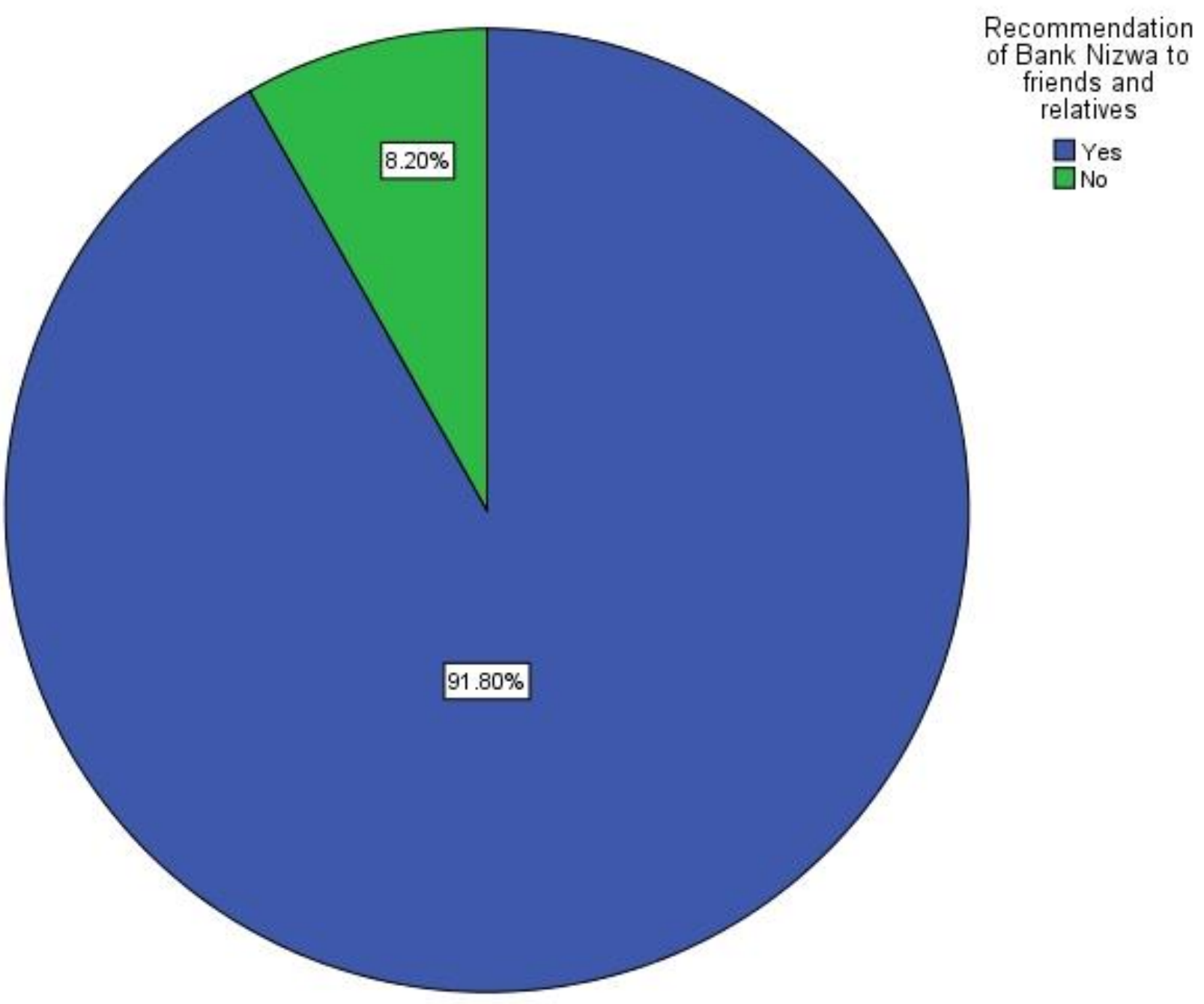

Figure 1.

The pie chart shows customers' recommendation to their relatives and friends to use bank Nizwa. Almost all the respondents said that they will recommend Bank Nizwa to their friends and relatives since most of the customers are satisfied with mobile banking services that are provided by Bank Nizwa. However, Bank Nizwa can improve their services .

\begin{tabular}{|c|c|c|c|c|}
\hline Nature of the services & Fully Satisfied & Satisfied & Somewhat satisfied & Dissatisfied \\
\hline $\begin{array}{l}\text { Request for cheque } \\
\text { Book }\end{array}$ & $58(48 \%)$ & $3327 \%$ & $29(24 \%)$ & $2(2 \%)$ \\
\hline Make a Transfer & $3225 \%$ & $3932 \%$ & $4738 \%$ & $5(4 \%)$ \\
\hline Manage Beneficiaries & $3428 \%$ & $4234 \%$ & $38(31 \%)$ & $8(7 \%)$ \\
\hline Instant Payment & $33(27 \%)$ & $4839 \%$ & $39(32 \%)$ & $2(2 \%)$ \\
\hline $\begin{array}{l}\text { Check Bank } \\
\text { Transaction }\end{array}$ & $29(24 \%)$ & $4537 \%$ & $34(27 \%)$ & $14(11.5 \%)$ \\
\hline Averages Percentage & $30 \%$ & $34 \%$ & $30 \%$ & $6 \%$ \\
\hline
\end{tabular}

Table 8. Evaluation of services provided by Mobile Banking in Bank Nizwa

The tabulated data of the above table clearly indicates that customers are not very comfortable with Mobile Banking. The above result shows $46 \%$ of respondents are satisfied by services for check book request, money transfer, manage beneficiaries, instant payment and check bank 


\section{Journal of Student Research}

Fourth Middle East College Student Research Conference, Muscat, Sultanate of Oman

transactions. Almost an equal percentage of customers responded that they are taking some services of the Mobile Banking and $6 \%$ of the customer are totally dissatisfied by the Mobile Banking services.

On the whole, the above result indicates that customers are satisfied with mobile banking in Bank Nizwa.

\begin{tabular}{|l|l|l|l|l|l|}
\hline \multirow{2}{*}{ Gender } & \multicolumn{4}{|c|}{ System comfortable of mobile banking } & \multirow{2}{*}{ Total } \\
\cline { 2 - 6 } & Friendly & Good & No idea & Difficult & \\
\hline Male & 9 & 31 & 7 & 4 & 51 \\
\hline Female & 28 & 37 & 5 & 1 & 71 \\
\hline Total & 37 & 68 & 12 & 5 & 122 \\
\hline
\end{tabular}

Table 9. Gender of the Respondents and System comfortable of mobile banking Primary Data

The above table shows the Respondents comfortable with Mobile Banking in Bank Nizwa. The results show that most of respondents (90\%) are comfortable with Mobile Banking at Bank Nizwa.

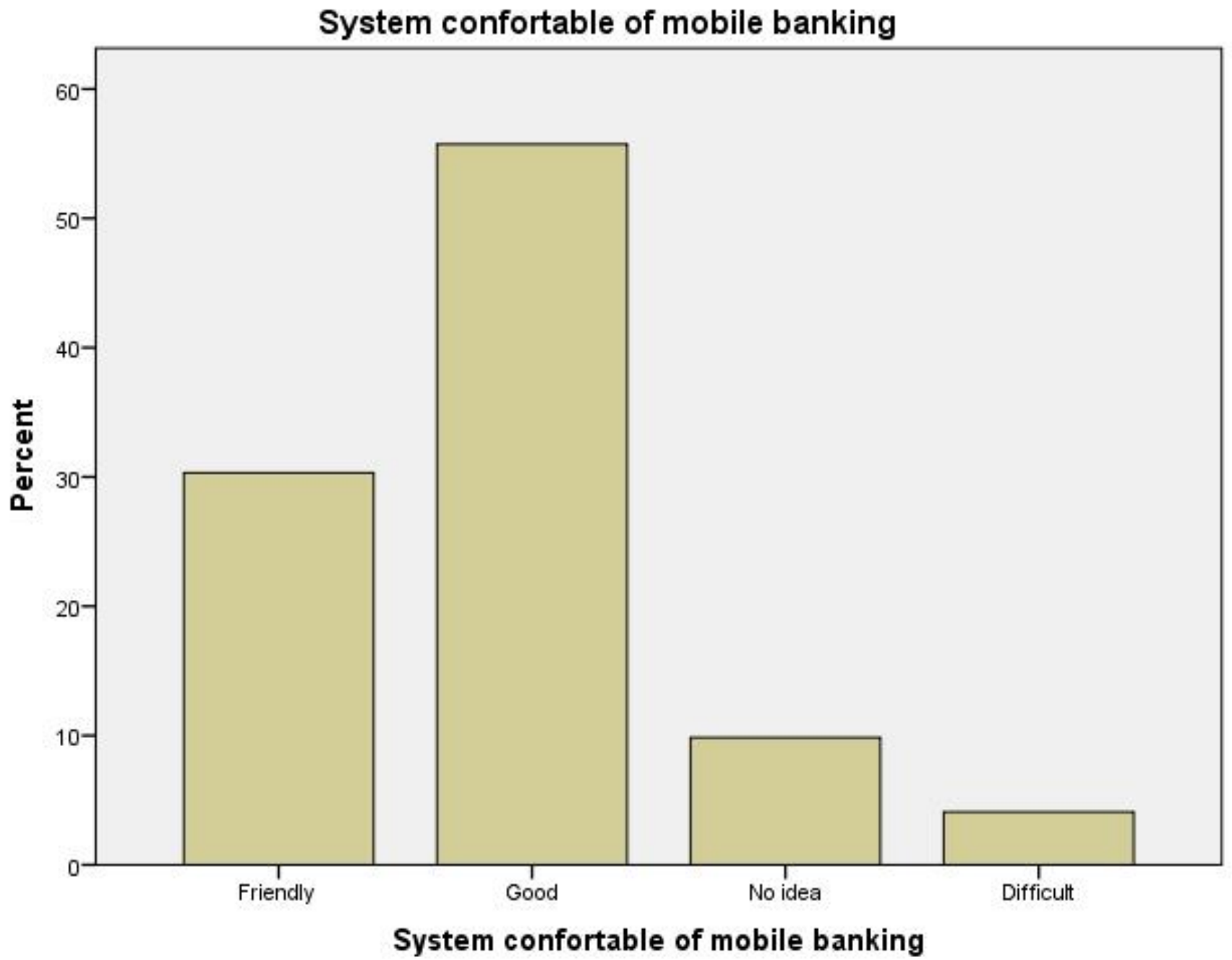

Figure 2.

\begin{tabular}{|l|l|l|l|l|l|}
\hline \multirow{2}{*}{ Gender } & \multicolumn{2}{|c|}{ Assessment regarding successful of mobile banking technology in Bank Nizwa } & \multirow{2}{*}{ TTotal } \\
\cline { 2 - 4 } & Very high & High & Average & Low & \\
\hline
\end{tabular}


Journal of Student Research

Fourth Middle East College Student Research Conference, Muscat, Sultanate of Oman

\begin{tabular}{|l|l|l|l|l|l|}
\hline Male & $2752.95 \%$ & $1427.45 \%$ & $917.67 \%$ & $11.96 \%$ & 51 \\
\hline Female & $1419.72 \%$ & $3853.52 \%$ & $1825.35 \%$ & $11.40 \%$ & 71 \\
\hline Total & 41 & 52 & 27 & 2 & 122 \\
\hline \multicolumn{2}{|l|}{ a. 2 cells (25.0\%) have expected count less than 5. The minimum expected count is .84. } \\
\hline
\end{tabular}

Table 10. Gender of the respondents and assessment regarding successful of mobile banking technology in

Bank Nizwa (Chi -Square)

Gender wise, male graded mobile banking technology in Bank Nizwa as very high (66\%) whereas female said that mobile banking technology in Bank Nizwa is only high (73\%) .

Applying the chi-square test on gender wise distribution of mobile banking in Bank Nizwa the result value of .002 .05 was obtained, proving that there is significant different on customer satisfaction with Bank Nizwa. Hence the research hypothesis has been accepted by proving that satisfaction wise co-relation was existing in successful of mobile technology.

\section{Finding and Recommendation}

\section{Main Finding}

On the basis of data collection and data analysis and application of statistical package (SPSS Ver. 20) following findings are envisaged in the research.

1. Majority of the respondents (81\%) are using mobile banking since last 1-4 years.

2. Moreover, $71 \%$ of respondents are operating their banking transactions in saving bank account.

3. Over $68 \%$ of the females are using mobile banking from 1-3 times per month.

4. On an average, $30 \%$ of the respondents communicated that they are either fully or somewhat satisfied with the technology and services of the mobile banking.

5. Whereas, $43 \%$ of respondents said that they are satisfied with the services of Bank Nizwa. But $6 \%$ of respondents dissatisfied by mobile banking service.

6. About $56 \%$ of respondents felt that mobile banking is good and comfortable. But $4 \%$ of respondents expressed their difficulties.

7. It is very interesting to know that over $80 \%$ of male customers are very successful in operating mobile banking and they are happy to take advantages of mobile banking services of bank Nizwa.

8. A small percentage (18\%) of respondents suggested improving the services of mobile banking like strengthening the website, speed of the Appe and so on.

9. Majority of customers (88\%) says that Bank Nizwa providing proper mobile services.

10. Over $85 \%$ customer said that the Bank Nizwa' mobile services are excellent and satisfied by the respondents.

11. Majority of customers recommends their friends and relatives to use Bank Nizwa because they have satisfied with the mobile banking service provided by the Bank Nizwa.

12. When researcher cross related the data of gender and success of mobile banking technology in bank Nizwa, high percentage of male opinioned that mobile banking is very successful ,However ,females are more satisfied with overall services of banks and application of chisquare test showed very close relationship between these two variables.

\section{Recommendations}

Through this study, a sample of customer satisfaction was taken, which is an important element in the successful to completion of the research project:

1. The researcher recommends that customer satisfaction can affect the productivity of Bank 


\section{Journal of Student Research}

Fourth Middle East College Student Research Conference, Muscat, Sultanate of Oman

Nizwa. There are some points that not satisfied much by the customers like: Make transaction, Request for cheque Book, manage Beneficiaries. Therefore, the Bank should reviews the customer response and assesses the customer's needs and services provided by the Bank. Put more efforts to improve the services to attract customers and compete with other banks.

2. It is recommended that Bank Nizwa should focus and see the problems faced by the customers and same has to be dealt with on a daily basis.

3. Whole of the research shows excellent result to Bank Nizwa, there are many of female using mobile banking (58\%) It has been suggested to focus more on customer satisfaction through mobile banking and how to use and benefit from them. In this spirit, it helps to make customers happy and satisfied with the services offered by the bank.

\section{Conclusion}

At the end of the study it was revealed that there were factors that helped in the customers satisfaction of mobile banking by (39\%) from the other side showed that (5\%) some services do not satisfy with customers. From this point of view, the problems that make customers unsatisfied have been studied. In addition, summary of this study was to examine the impact of mobile banking factors and services at Nizwa Bank, Sultanate of Oman.

\section{Acknowledgement}

The research would not have been completed without the support, and encouragement of many concerned people. I thank my father who had the motivation and great incentive to make success of my project also, my friends who supported me. Special thanks to my supervisor, Dr. Madhava who urged me and helped me complete my research project correctly .I also thank the employees of Bank Nizwa for their cooperation in disseminating some information about the bank

\section{Reference}

1. Financial-services. (2018). GCC banks customers. [Online]. Available at https://www.ey.com/em/en/industries/financial-services/banking---capital-markets/ey-gulfcooperation-council-digital-banking-report-2015 Assessed 1 Oct 2019

2. Banknizwa.om. (2018). Our Story | Bank Nizwa - First Islamic bank in Oman. [Online].Available at http://www.banknizwa.om/about/our-story/ Assessed 3Oct 2019

3. Bank Nizwa. (2018).Mobile Banking App. [Online].Available at http://www.banknizwa.om/services/personal-banking/ways-of-banking/mobile-banking-app/ Assessed 3 Oct 2019

4. Researchgate.net. (2018). The Impact of Mobile Banking on Enhancing Customers' ESatisfaction: An Empirical Study on Commercial Banks in Jordan.[online].Available at https://www.researchgate.net/publication/265725145 The_Impact_of_Mobile_Banking_on_E nhancing_Customers'_E-Satisfaction_An_Empirical_Study_on_Commercial_Banks_in_Jordan Assessed 5 Oct 2019

5. Researchgate.net. (2018). Impact of Mobile Banking Services on Customer Satisfaction: A Study on Sri Lankan State Commercial Bank. [Online]. Available at https://www.researchgate.net/publication/280581182_Impact_of_Mobile_Banking_Services on Customer SatisfactionA_Study on Sri_Lankan_State_Commercial_Bank Assessed 5 Oct $20 \overline{19}$

6. Inderscience. (2019). Factors leading to customer satisfaction: an empirical study of retail banking in Oman. [Online]. Available at https://www.inderscienceonline.com/doi/abs/10.1504/IJEBR.2018.095346Assessed 8 Oct 2019 


\section{Journal of Student Research}

Fourth Middle East College Student Research Conference, Muscat, Sultanate of Oman

7. Commercecentral.com. (2018). Journal of Internet Banking and

Commerce.[online].Available at http://www.icommercecentral.com/open-access/the-impact-o f-mobile-banking-on-customer-satisfaction-commercial-banks-of-namibia-keetmanshoop.pdf Assessed 9 Oct 2019

8. Taylor \& Francis. (2017).Service quality dimensions and customer satisfaction.[Online]. Available at https://www.tandfonline.com/eprint/pIqk9KQ3wRNR8y2msGAm/fullAssessed 14 Oct 2019

9. Strategicjournals.com. (2018). Effect of mobile banking strategy on customer satisfaction: a case of commercial banks in ongata rongai. [Online].Available at http://strategicjournals.com/index.php/journal/article/viewFile/347/370 Assessed 17 Oct 2019 